\title{
Influence of heating and acidification on the flavor of whey protein isolate
}

\author{
S. S. White, K. M. Fox, S. M. Jervis, and M. A. Drake ${ }^{1}$ \\ Department of Food, Bioprocessing and Nutrition Sciences, Southeast Dairy Food Research Center, \\ North Carolina State University, Raleigh 27695
}

\begin{abstract}
Previous studies have established that whey protein manufacture unit operations influence the flavor of dried whey proteins. Additionally, manufacturers generally instantize whey protein isolate (WPI; $\geq 90 \%$ protein) by agglomeration with lecithin to increase solubility and wettability. Whey protein isolate is often subjected to additional postprocessing steps in beverage manufacturing, including acidification and heat treatment. These postprocessing treatments may further influence formation or release of flavors. The objective of the first study was to characterize the effect of 2 processing steps inherent to manufacturing of acidic protein beverages (acidification and heat treatment) on the flavor of non-instant WPI. The second study sought to determine the effect of lecithin agglomeration, a common form of instantized (INST) WPI used in beverage manufacturing, on the flavor of WPI after acidification and heat treatment. In the first experiment, commercial non-instantized (NI) WPI were rehydrated and evaluated as is (control); acidified to $\mathrm{pH} 3.2$; heated to $85^{\circ} \mathrm{C}$ for $5 \mathrm{~min}$ in a benchtop high temperature, short time (HTST) pasteurizer; or acidified to 3.2 and heated to $85^{\circ} \mathrm{C}$ for $30 \mathrm{~s}$ (AH-HTST). In the second experiment, INST and NI commercial WPI were subsequently evaluated as control, acidified, heated, or AH-HTST. All samples were evaluated by descriptive sensory analysis, solid-phase microextraction (SPME), and gas chromatography-mass spectrometry. Acidification of NI WPI produced higher concentrations of dimethyl disulfide (DMDS) and sensory detection of potato/brothy flavors, whereas heating increased cooked/sulfur flavors. Acidification and heating increased cardboard, potato/ brothy, and malty flavors and produced higher concentrations of aldehydes, ketones, and sulfur compounds. Differences between INST and NI WPI existed before treatment; INST WPI displayed cucumber flavors not present in NI WPI. After acidification, INST WPI were
\end{abstract}

Received July 12, 2012.

Accepted November 23, 2012.

${ }^{1}$ Corresponding author: mdrake@unity.ncsu.edu distinguished by higher intensity of cucumber flavor and higher concentrations of E-2-nonenal. No perceivable differences were observed between INST and NI WPI after heating; sulfur and eggy flavors increased in both types of WPI. After treatment, AH-INSTHTST samples were differentiated from AH-NI-HTST by grassy/hay and grainy flavor and increased lipid oxidation products. Further processing of WPI in food applications has negative effects on the flavor contributions of WPI.

Key words: whey protein isolate, flavor, acidification/heat treatment, lecithin

\section{INTRODUCTION}

Whey protein and its derivatives have been added to a growing number of functional foods. Whey ingredients add not only protein to beverage applications, but provide essential amino acids and functional properties. For this reason, whey protein readily lends itself to sports drinks, infant formula, and meal replacement beverages. In ingredient applications, whey protein is expected to have a bland flavor; however, whey protein ingredients can display off-flavors such as cardboard, animal, soapy, cucumber, and brothy (Carunchia Whetstine et al., 2005; Drake, 2006; Wright et al., 2006, 2009). Research has associated these undesirable flavors with multiple variables along the whey manufacture process including milk type, cheese starter culture, processing conditions, and storage conditions (Carunchia Whetstine et al., 2003, 2005; Tomaino et al., 2004; Croissant et al., 2009; Gallardo-Escamilla et al., 2005; Wright et al., 2006, 2009; Whitson et al., 2011). The flavor variability of dried whey protein affects the flavor profile and consumer acceptance of products containing whey protein (Childs et al., 2007; Wright et al., 2009; Evans et al., 2010). Off-flavors may be successfully masked, depending on the perceived intensity of the off-flavor, the nature/description of the off-flavor, and characteristics of the product application. Alternatively, optimal process and storage conditions can be applied to reduce or eliminate off-flavors in the dried whey protein.

Whey protein isolate (WPI) is a value-added dried whey product that contains at least $90 \%$ protein. Whey 
protein isolate is typically added to functional beverages at levels of 3 to $8 \%$ protein ( 3 to $8 \mathrm{~g}$ per $100-\mathrm{mL}$ serving; Hazen, 2003). In beverage manufacturing, dried whey protein is subjected to additional postprocessing steps; including acidification $(\mathrm{pH}<4.6)$ for clarity and heat treatment (typically $88^{\circ} \mathrm{C}$ for $120 \mathrm{~s}$ ) for shelf stability (Prendergast, 1985; Rittmanic, 2006; LaClair and Etzel, 2010). In addition to stability concerns, flavor is an essential component in the consumer acceptance of whey protein beverages. Cardboard, soapy, cabbage, and potato are documented off-flavors associated with whey protein beverages, and postprocessing of the protein in the beverage may further affect the flavor and acceptance of the finished product (Childs et al., 2007; Wright et al., 2009; Evans et al., 2010).

Whey protein isolate for beverage manufacturing may also be agglomerated to increase wettability and solubility of the protein ingredient. In the process of agglomeration, the dried powder forms clumps and particles that create pores in the powder and increase dispersibility. Methods of instantization include rewet and single-pass agglomeration. In rewet agglomeration, dry product is placed on a fluidized bed and steam or lecithin is applied (Henning et al., 2006; Wright et al., 2009). The partial wetting allows sticking and particle formation. An alternate method is single-pass agglomeration. In this process, instantization occurs as the product is spray dried. A multi-nozzle system is used to redirect dry product into the path of wet product (Henning et al., 2006). A common form of agglomeration includes addition of soy lecithin to increase wettability and solubility. Soy lecithin is desired because it is classified as a nutraceutical food due to its phospholipid constituents (Colbert, 1998). However, lecithin-associated volatiles have been documented in instantized products and may contribute cucumber, fatty, and cardboard flavors (Mortenson et al., 2008; Wright et al., 2009). Wright et al. (2009) documented that WPI instantized with lecithin had decreased shelf stability due to increased lipid oxidation products. To our knowledge, no studies have documented the impact of instantization on the flavor of WPI and its possible role in the flavor of acidified whey protein beverages.

A better understanding of how postprocessing steps (heating and acidification) affect the flavor of WPI may lead to the identification of methods to reduce or minimize WPI flavor contributions in beverages or lead to the identification of key compounds that can be masked to produce a more palatable product. The objective of the first study was to characterize the effects of 2 beverage-processing steps (acidification and heating) on the flavor of WPI. The second study sought to investigate possible flavor contributions from agglomeration with lecithin. These objectives were achieved through sensory and instrumental analyses of WPI, with and without agglomeration, under various treatments [control $(\mathbf{C O N})$, acidified (ACD), heated (H-batch), and acidified and heated (AH-HTST).

\section{MATERIALS AND METHODS}

\section{Sample Acquisition and Preliminary Assessments}

Natural variance between commercial suppliers of WPI is common and expected due to processing variation and equipment differences (Carunchia Whetstine et al., 2005). To account for this variance, 5 different commercial suppliers from throughout the United States each provided 2 lots of non-instant WPI manufactured from Cheddar whey (experiment 1). To investigate the effect of instantization on WPI, 2 of these suppliers also provided an additional 2 lots of instantized (INST) and 2 lots of non-instantized (NI) WPI manufactured from Cheddar whey (experiment 2). These 2 suppliers were able to instantize samples using single-pass agglomeration. Single-pass agglomeration, as opposed to rewet agglomeration, was chosen to minimize extraneous variables, such as initial product age. All samples were stored at $-20^{\circ} \mathrm{C}$ upon receipt.

Chemical standards were obtained from Sigma-Aldrich (St. Louis, MO) with some exceptions: dimethyl sulfide, Z-4-heptenal, phenylacetaldehyde, octanal, and $o$-aminoacetophenone were obtained from Acros Organics (Morris Plains, NJ); nonanal, 1-hexen-3-one, 2 -pentyl furan, $\delta$-decalactone, and $\delta$-dodecalactone were obtained from Alfa Aesar (Ward Hill, MA); 2-acetyl-2-thiazoline was obtained from AstaTech Inc. (Bristol, PA); 2-acetyl-thiazole, 2-nonanone, and ethyl octanoate were obtained from SAFC Supply Solutions (St. Louis, MO); p-cresol, butyric acid, and benzaldehyde were obtained from Fluka Chemie GmbH (Buchs, Switzerland); and 2,5-octanedione was obtained from Frinton Laboratories Inc. (Vineland, NJ).

Proximate Analysis. All WPI obtained from each supplier were analyzed for protein, fat, moisture, ash, and mineral content in duplicate. Total protein was measured by the Kjeldahl method (AOAC International, 2000; method number 991.20; 33.2.11) and total nitrogen was multiplied by a 6.38 conversion factor. Total fat content was determined by Mojonnier extraction (AOAC International, 2000; method number $989.05 ; 33.2 .26)$ and total moisture content by vacuum oven drying (AOAC International, 2000; method number 990.20; 33.2.44). Total ash and minerals were measured by North Carolina State University Analytical Services Laboratory (Raleigh, NC) using a dry ash method paired with inductively coupled plasma optical emission spectroscopy (Lloyd et al., 2009). 
Volatile FFA Analysis. A method adapted from Tomaino et al. (2001) was used to measure volatile FFA. This analysis was conducted on untreated WPI to identify potential intrinsic differences in FFA that may have contributed to flavor differences initially and after treatments. All WPI were rehydrated to $10 \%$ (wt/ vol) solids and the $\mathrm{pH}$ was adjusted to $\mathrm{pH} 2.0$ with 3.3 $M \mathrm{HCl}$ (Sigma-Aldrich). After equilibration to room temperature $\left(25^{\circ} \mathrm{C}\right)$ in a water bath, $5 \mathrm{~g}$ of sample was added to a 20-mL screw-cap vial (Microliter Analytical Supplies Inc., Suwanee, GA) with $5 \mu \mathrm{L}$ of internal standard $[1 \mathrm{mg}$ of heptadecanoic acid $(\mathrm{C} 17) / \mathrm{mL}$ of methanol (Sigma-Aldrich)] and a stir bar (Fisher Scientific, Pittsburgh, PA). The vials were heated to $110^{\circ} \mathrm{C}$ for 40 min with the stir module on high. During the 40-min heating time, volatiles were extracted by a $30-\mu \mathrm{m}$-thick polydimethylsiloxane fiber (Supelco Inc., Bellefonte, PA) attached to a fiber holder (Supelco Inc.) set to a depth of $1 \mathrm{~cm}$. Volatiles were analyzed, in triplicate, by an Agilent 5975 GC-MS unit (Agilent Technologies Inc., Santa Clara, CA) with a ZB-FFAP column (30-m length $\times 0.25-\mathrm{mm}$ i.d. $\times 0.25-\mu \mathrm{m}$ film thickness; Zebron; Phenomenex Inc., Torrance, CA) and the flame ionization detector set at $250^{\circ} \mathrm{C}$. The oven temperature, initially $100^{\circ} \mathrm{C}$, was held for $2 \mathrm{~min}$ and then increased at $10^{\circ} \mathrm{C} / \mathrm{min}$ to $245^{\circ} \mathrm{C}$, and was held for $10 \mathrm{~min}$. Compounds were identified by comparison of retention time to authentic standards. Relative abundance for each FFA was calculated based on the internal standard calculated recovery.

\section{Processing Treatments}

ACD Samples. All WPI samples were rehydrated to $10 \%$ solids (wt/vol) with deionized water. The rehydrated whey was then acidified to $\mathrm{pH} 3.2$ using a 2 M 1:1 blend of phosphoric (Mallinckrodt Chemicals, Phillipsburg, NJ) and citric (J. T. Baker, Mallinckrodt Baker Inc., Phillipsburg, NJ) acids to replicate industry practices (Prendergast, 1985; Rittmanic, 2006). Preliminary experiments were conducted to determine the volume of acid required to acidify the samples. This volume was subtracted from the total water added to retain $10 \%$ solids in the samples. The solids content was verified with the Smart System 5 moisture/solids analyzer (CEM Corp., Matthews, NC). All processing treatments were manufactured in $900-\mathrm{mL}$ batches.

$\boldsymbol{H}$-batch Samples. Due to protein coagulation observed in preliminary testing, the heat-treated samples could not be passed through a HTST coil. Therefore, rehydrated samples were batch heated to $85^{\circ} \mathrm{C}$ in a digital shaker water bath (VWR apparatus, West Chester, PA) with an Arrow 1750 stirrer placed inside the sample (Arrow Engineering Inc., Hillside, NJ). Once the sam- ples reached temperature $\left(85^{\circ} \mathrm{C}\right.$; approximately $\left.20 \mathrm{~min}\right)$ they were held for $5 \mathrm{~min}$ before cooling, with constant stirring, to $4^{\circ} \mathrm{C}$ in an ice bath (approximately $15 \mathrm{~min}$ ).

AH-HTST Samples. Rehydrated samples were acidified to $\mathrm{pH} 3.2$ with the same methods described for the ACD samples. Samples were then run through a benchtop HTST pasteurizer so that the sample maintained $85^{\circ} \mathrm{C}$ for $30 \mathrm{~s}$. The benchtop HTST consisted of a peristaltic pump (Masterflex L/S; Cole-Parmer North America, Vernon Hills, IL) forcing the sample through a one-eighth-inch $(0.3175-\mathrm{cm})$ stainless steel coil (Cole-Parmer North America) that was submerged in a heated water bath (VWR International LLC, West Chester, PA). The flow rate was $170 \mathrm{~mL} / \mathrm{min}$ and the design was adapted from Cole and Jones (1990). Once the samples were heated, they were immediately cooled, with constant stirring, to $4^{\circ} \mathrm{C}$ in an ice bath (approximately $15 \mathrm{~min}$ ).

\section{Descriptive Sensory Analysis}

Processed WPI (ACD, H-batch, and AH-HTST) and untreated CON samples were dispensed into lidded soufflé cups with random 3-digit codes, tempered to room temperature $\left(25^{\circ} \mathrm{C}\right)$ for $1 \mathrm{~h}$, and evaluated for flavor and aroma intensity. Trained descriptive panelists (10 panelists: 9 females and 1 male, ages 23 to $50 \mathrm{yr}$ ) each with over $150 \mathrm{~h}$ of experience with sensory analysis of dried whey proteins, used an established dried ingredient lexicon (Wright et al., 2009) to evaluate the WPI. Attributes were scaled using a 0 - to 15-point universal Spectrum scale (Meilgaard et al., 1999). With randomized presentation, each sample was evaluated in duplicate by each panelist. Paper ballots or Compusense five software (version 4.8; Compusense Inc., Guelph, ON, Canada) were used for data collection.

\section{Solid-Phase Microextraction GC-MS}

All WPI were subjected to solid-phase microextraction (SPME) GC-MS for extraction and identification of volatile compounds in triplicate. The sample preparation and SPME GC-MS method were modified from the method used by Wright et al. (2006). An aliquot (5 $\mathrm{mL}$ ) of sample was placed in $20-\mathrm{mL}$ autosampler vials with steel screw tops containing silicon septa faced in Teflon (Microliter Analytical Supplies Inc.). Internal standard solution ( $81 \mathrm{mg} / \mathrm{kg}$ of 2-methyl-3-heptanone in ether; Sigma-Aldrich, Milwaukee, WI) and 10\% (wt/ vol) sodium chloride (Fisher Scientific) were added to the samples. Samples were injected using a CTC Analytics Combi PAL autosampler (Leap Technologies, Carrboro, NC) attached to an Agilent 6890N GC (Agilent Technologies Inc.). Samples were held at $5^{\circ} \mathrm{C}$ 
before fiber exposure. Samples were equilibrated at $40^{\circ} \mathrm{C}$ for $25 \mathrm{~min}$ before exposure to a 3-phase divinylbenzene/Carboxen/polydimethylsiloxane (DVB/CAR/ PDMS) fiber (Supelco Inc.) at $31 \mathrm{~mm}$ for $30 \mathrm{~min}$, with 4 -s pulsed agitation at $250 \mathrm{rpm}$. Fibers were injected for $5 \mathrm{~min}$ at a depth of $50 \mathrm{~mm}$.

The initial temperature of the $\mathrm{GC}$ method was $40^{\circ} \mathrm{C}$ for 3 min, with a ramp rate of $10^{\circ} \mathrm{C} / \mathrm{min}$ until $90^{\circ} \mathrm{C}$ was reached, and this was then increased at a rate of $5^{\circ} \mathrm{C} /$ min to $200^{\circ} \mathrm{C}$, held for $10 \mathrm{~min}$, and finally increased at a rate of $20^{\circ} \mathrm{C} / \mathrm{min}$ to $250^{\circ} \mathrm{C}$ and held for $5 \mathrm{~min}$. Solidphase microextraction fibers were then introduced into the split/splitless injector at $250^{\circ} \mathrm{C}$ at a pressure of $48.68 \mathrm{kPa}$ with helium as the carrier gas with a purge flow of $169,737 \mathrm{~cm} / \mathrm{s}$. A ZB-5MS column (30-m length $\times 0.25$-mm i.d. $\times 0.25-\mu \mathrm{m}$ film thickness; Zebron; Phenomenex Inc.) was used for all analyses, with a constant flow rate of $34 \mathrm{~cm} / \mathrm{s}$. The purge time was set at $1 \mathrm{~min}$. The MS transfer line was maintained at $250^{\circ} \mathrm{C}$ with the quad at $150^{\circ} \mathrm{C}$ and the source at $250^{\circ} \mathrm{C}$. Identification of compounds was based on a comparison of retention indices and mass spectra of the unknowns against authentic standards injected under identical conditions. Retention indices were calculated with the use of an alkane series (Fluka Chemie GmbH; van den Dool and Kratz, 1963).

\section{Quantification of Volatile Compounds}

Compounds that showed significant differences between treatments by relative abundance (results not shown) were selected for quantification with external standard curves. Authentic standards were used to generate 4-point standard curves to determine the concentration of the selected compounds. Methanethiol and (E,E)-3,5-octadien-2-one were not readily available. Therefore, standard curves were prepared with dimethyl sulfide and 2,5-octanedione, respectively, to approximate chemical properties of the unavailable compounds. Solutions were made to span 0 to $200 \mu \mathrm{g} /$ $\mathrm{kg}$ in neutral and acidified (see ACD samples) liquid whey retentate $(23.0 \%$ solids, $19.55 \%$ protein) diluted to $9 \%$ (wt/vol) protein with HPLC-grade water (EMD Chemicals Inc., Gibbstown, NJ). Cold (below $10^{\circ} \mathrm{C}$ ) UF liquid whey retentate from unbleached Cheddar whey manufactured in the North Carolina State University pilot plant (Listiyani et al., 2011), was chosen as a minimally odored matrix with protein composition similar to WPI. External standard curves were evaluated by SPME GC-MS in selective ion monitoring (SIM) mode.

\section{Statistical Analysis}

Flavor variation in WPI was inherent to the study due to the selection of commercial WPI from several manu- facturers (Carunchia Whetstine et al., 2005; Wright et al., 2009). However, our objective was to evaluate the effect of beverage processing steps (acidification and heating) on flavor contributions of WPI rather than WPI flavor variability. Therefore, data from multiple suppliers were averaged in descriptive and GC-MS analyses to better investigate how beverage-processing steps affected WPI flavor, independent of manufacturer. Proximate analyses and sensory and instrumental results were analyzed using XLSTAT statistical software (Addinsoft Inc., New York, NY). Analysis of variance with means separation and principal component analyses were conducted to test significant differences between treatments $(\mathrm{CON}, \mathrm{ACD}, \mathrm{H}-$ batch, and $\mathrm{AH}-$ HTST) and how agglomerated samples were differentiated across sensory and instrumental measurements.

\section{RESULTS AND DISCUSSION}

\section{Baseline Analyses of Commercial WPI for Experiments 1 and 2}

Proximate Analysis. Compositional differences existed among the WPI produced by the 5 different suppliers in experiment 1 ( $P \leq 0.05$; results not shown). Protein content ranged from 91 to $95 \%$ (dry-weight basis), fat content between 0.2 to $0.7 \%$ (dry-weight basis), and ash content between 2.0 to $2.9 \%$ (dry-weight basis). No statistical difference existed in moisture content $(4.1 \pm 0.67 \% ; P>0.05)$. Phosphorous content ranged from 650 to $2,800 \mathrm{mg} / \mathrm{kg}$, calcium content between 130 and $6,300 \mathrm{mg} / \mathrm{kg}$, magnesium content between 17 and $8,300 \mathrm{mg} / \mathrm{kg}$, potassium content between 240 and 4,500 $\mathrm{mg} / \mathrm{kg}$, sulfur content between 11,000 and 14,000 mg/ $\mathrm{kg}$, and sodium content between 1,300 and 7,100 ppm $(P \leq 0.05)$. The differences in proximate analysis of WPI were likely due to different processing parameters at each manufacturing facility (Carunchia Whetstine et al., 2005) and all values were within expected ranges (Holt et al., 1999; Evans et al., 2010). These characteristic differences were also documented among the WPI in experiment 2 along with expected increases in fat content due to the instantization process (Table 1).

Volatile FFA Analysis. Volatile FFA analysis was conducted to document any intrinsic differences in volatile FFA composition. The relative abundance of volatile FFA in WPI from 5 different manufacturers was variable, as expected ( $P>0.05$; results not shown). Interestingly, when compared with non-instant WPI, instant WPI was, on average, 5 times higher in linoleic and 7 times higher in linolenic FA (Table 2). These 2 readily oxidized species are abundant in lecithin derived from plant sources, and unmodified soy lecithin is 
Table 1. Proximate analysis of instantized (INST) and non-instantized (NI) whey protein isolate (WPI; experiment 2$)^{1}$

\begin{tabular}{|c|c|c|c|c|}
\hline \multirow[b]{2}{*}{ Item } & \multicolumn{2}{|c|}{ Supplier 1} & \multicolumn{2}{|c|}{ Supplier 2} \\
\hline & NI WPI & INST WPI & NI WPI & INST WPI \\
\hline Protein (\%, dry-weight basis) & $92^{\mathrm{a}}$ & $92^{\mathrm{a}}$ & $93^{\mathrm{a}}$ & $92^{\mathrm{a}}$ \\
\hline Fat (\%, dry-weight basis) & $0.90^{\mathrm{ab}}$ & $1.8^{\mathrm{b}}$ & $0.70^{\mathrm{a}}$ & $1.2^{\mathrm{ab}}$ \\
\hline Moisture (\%) & $5.1^{\mathrm{a}}$ & $4.5^{\mathrm{a}}$ & $4.8^{\mathrm{a}}$ & $4.1^{\mathrm{a}}$ \\
\hline Ash (\%, dry-weight basis) & $2.7^{\mathrm{a}}$ & $2.8^{\mathrm{a}}$ & $2.6^{\mathrm{a}}$ & $2.7^{\mathrm{a}}$ \\
\hline Phosphorous (mg/kg) & $2,300^{\mathrm{bc}}$ & $2,400^{\mathrm{c}}$ & $1,700^{\mathrm{a}}$ & $1,900^{\mathrm{ab}}$ \\
\hline Calcium $(\mathrm{mg} / \mathrm{kg})$ & $7.200^{\mathrm{b}}$ & $6.900^{\mathrm{b}}$ & $670^{\mathrm{a}}$ & $820^{\mathrm{a}}$ \\
\hline Magnesium $(\mathrm{mg} / \mathrm{kg})$ & $840^{\mathrm{b}}$ & $860^{\mathrm{b}}$ & $94^{\mathrm{a}}$ & $120^{\mathrm{a}}$ \\
\hline Potassium $(\mathrm{mg} / \mathrm{kg})$ & $2,800^{\mathrm{a}}$ & $3,100^{\mathrm{a}}$ & $1,600^{\mathrm{a}}$ & $1,800^{\mathrm{a}}$ \\
\hline Sulfur $(\mathrm{mg} / \mathrm{kg})$ & $11,000^{\mathrm{a}}$ & $10,000^{\mathrm{a}}$ & $11,000^{\mathrm{a}}$ & $11,000^{\mathrm{a}}$ \\
\hline Sodium (mg/kg) & $1,300^{\mathrm{a}}$ & $1,300^{\mathrm{a}}$ & $8,700^{\mathrm{b}}$ & $8,700^{\mathrm{b}}$ \\
\hline
\end{tabular}

${ }^{a-c}$ Means within a row not followed by the same letter are different $(P \leq 0.05$; statistical analysis with means separations using Fisher's LSD with 95\% CI).

${ }^{1}$ Means represent duplicate lots from 2 suppliers.

approximately $30 \%$ linoleic acid and $3 \%$ linolenic acid (Schneider, 1989). Consistent with these results, soy is the most common lecithin type used in the whey protein industry and may contribute highly oxidized species or substrates to the protein ingredient.

\section{Experiment 1. Effect of Beverage Processing Steps on Non-Instant WPI}

Descriptive Analysis. Descriptive analysis was performed on non-instant WPI before and after the various processing treatments to document the flavor profiles of these samples. In general, beverage processing steps (ACD, H-batch, and AH-HTST) increased overall aroma, cardboard, potato/brothy, soapy, and astringent attributes (Table 3). These attributes were highest in AH-HTST WPI. Cardboard, potato, soapy, and astringency are off-notes previously documented in whey protein beverages that contribute to decreased consumer acceptance (Childs et al., 2007; Wright et al., 2009; Evans et al., 2010).

Compared with the untreated controls, A WPI were characterized by higher intensities of astringency and sour taste as expected. Other flavors, not present in control WPI, were also documented following processing treatments. Animal/tortilla and cooked/sulfur were documented in H-batch WPI and these samples also had higher astringency and overall aroma compared with controls. Proteolysis of WPI can result in an undesirable animal/wet dog flavor and also has been associated with bitterness and astringency (Harwalkar et al., 1993; Lee et al., 1996a). Degradation of amino acids is likely due to the heat treatment. Additionally, the 2 main protein strands in whey ( $\beta-\mathrm{LG}$ and $\alpha$-LA) denature when heated and release sulfur-containing amino acids, which can further degrade into an array of

Table 2. Volatile FFA concentrations $(\mu \mathrm{g} / \mathrm{kg})$ in non-instantized (NI) and instantized (INST) whey protein isolate (WPI; experiment 2) ${ }^{1}$

\begin{tabular}{lccccc}
\hline & \multicolumn{2}{c}{ Supplier 1} & & \multicolumn{2}{c}{ Supplier 2} \\
\cline { 2 - 3 } \cline { 5 - 6 } FFA & NI WPI & INST WPI & & NI WPI & INST WPI \\
\hline Butyric & $0.0020^{\mathrm{b}}$ & $0.0020^{\mathrm{b}}$ & & $0.0050^{\mathrm{ab}}$ & $0.0070^{\mathrm{a}}$ \\
Hexanoic & $0.013^{\mathrm{a}}$ & $0.0050^{\mathrm{a}}$ & & $0.020^{\mathrm{a}}$ & $0.021^{\mathrm{a}}$ \\
Octanoic & $0.0080^{\mathrm{b}}$ & $0.032^{\mathrm{a}}$ & & $0.030^{\mathrm{a}}$ & $0.028^{\mathrm{a}}$ \\
Decanoic & $0.11^{\mathrm{a}}$ & $0.10^{\mathrm{a}}$ & & $0.15^{\mathrm{a}}$ & $0.18^{\mathrm{a}}$ \\
Dodecanoic & $0.74^{\mathrm{a}}$ & $0.60^{\mathrm{a}}$ & & $0.58^{\mathrm{a}}$ & $0.60^{\mathrm{a}}$ \\
Tetradecanoic & $3.0^{\mathrm{a}}$ & $2.1^{\mathrm{a}}$ & & $2.4^{\mathrm{a}}$ & $2.1^{\mathrm{a}}$ \\
Hexadecanoic & $5.5^{\mathrm{a}}$ & $5.5^{\mathrm{a}}$ & & $6.7^{\mathrm{a}}$ & $9.1^{\mathrm{a}}$ \\
Octadecanoic & $0.54^{\mathrm{b}}$ & $0.63^{\mathrm{b}}$ & & $2.8^{\mathrm{a}}$ & $3.2^{\mathrm{a}}$ \\
Oleic & $2.1^{\mathrm{b}}$ & $2.3^{\mathrm{b}}$ & & $5.6^{\mathrm{a}}$ & $7.2^{\mathrm{a}}$ \\
Linoleic & $0.18^{\mathrm{b}}$ & $1.7^{\mathrm{b}}$ & & $2.0^{\mathrm{b}}$ & $9.2^{\mathrm{a}}$ \\
Linolenic & $0.045^{\mathrm{b}}$ & $0.16^{\mathrm{ab}}$ & & $0.095^{\mathrm{ab}}$ & $0.83^{\mathrm{a}}$
\end{tabular}

${ }^{\mathrm{a}, \mathrm{b}}$ Means within a row not followed by the same letter are different $(P \leq 0.05$; statistical analysis with means separations using Fisher's LSD with 95\% CI).

${ }^{1}$ Means represent duplicate lots from 2 suppliers. 
volatile compounds and sulfurous aromas (Linden and Lorient, 1999).

The combination of heating and acidification resulted in higher intensities of overall aroma, cardboard, potato/brothy, and soapy flavors, astringency, sour taste as well as detection of a malty flavor and soapy aftertaste. Cardboard and malty flavors have been previously documented in whey proteins and are attributed to compounds produced by lipid and protein oxidation and Strecker degradation; respectively (Singh et al., 2003; Whitson et al., 2010). Heat treatment can stimulate the formation of Maillard reaction intermediates, which can then react with $\alpha$-amino acids to form Strecker degradation compounds (Singh et al., 2003; Leksrisompong et al., 2010). In follow-up sessions, the sensory panel described the soapy aftertaste as medium-chain FFA in nature. Free fatty acids are lipolysis products and have been previously documented in whey protein concentrate 80 (WPC80) and WPI (Tomaino et al., 2001; Carunchia Whetstine et al., 2005). Protein degradation and decreased matrix $\mathrm{pH}$ have been shown to enhance the perceived intensity of FFA flavor in cheese (Adda et al., 1982). Similarly, postprocessing treatments of whey protein may have the same effect on perceived FFA intensity. Processing of WPI by acidification and heat treatment subjects the protein solution or beverage to several chemical reactions that contribute to changes in flavor. It is important to note, however, that because the heat treatments of WPI could not be replicated between heating alone with no acidification (batch heat treatment, H-batch) and heating and acidification (HTST heat treatment, AH-HTST), some of the differences observed may be due to differences in the heat treatment.

$\boldsymbol{G C}$ - $\boldsymbol{M S}$. Volatile analysis revealed significant differences between the unprocessed and processed WPI (Table 4). The treated WPI were generally lower than the CON in several compounds $(P<0.05)$, in contrast to sensory results that demonstrated increases in intensity of certain flavors. Protein denaturation induced by acidification or heating (or both), can expose reactive sites in the amino acid sequence that have great affinity for binding volatile compounds (Hunt and Dalgleish, 1994).

Although not detected in the control, potato/brothy flavor was noted in processed WPI and was highest in AH-HTST WPI (Table 3). Several compounds are purported to contribute to potato/brothy flavor, including 2- and 3-methyl butanal, decanal, phenylacetaldehyde, methoxy pyrazines, methional, dimethyl disulfide (DMDS), and dimethyl trisulfide (DMTS; Jansky, 2010). Dimethyl sulfide (DMS), DMDS, and 2-phenethanol were increased in WPI after acidification $(P \leq 0.05$; Table 4$)$. Sulfur compounds (DMS and 
Table 4. Selected volatile compound concentration $(\mu \mathrm{g} / \mathrm{kg})$ by solid-phase microextraction (SPME) GC-MS in non-instantized whey protein isolate (WPI) after beverage-processing steps (experiment 1$)^{1}$

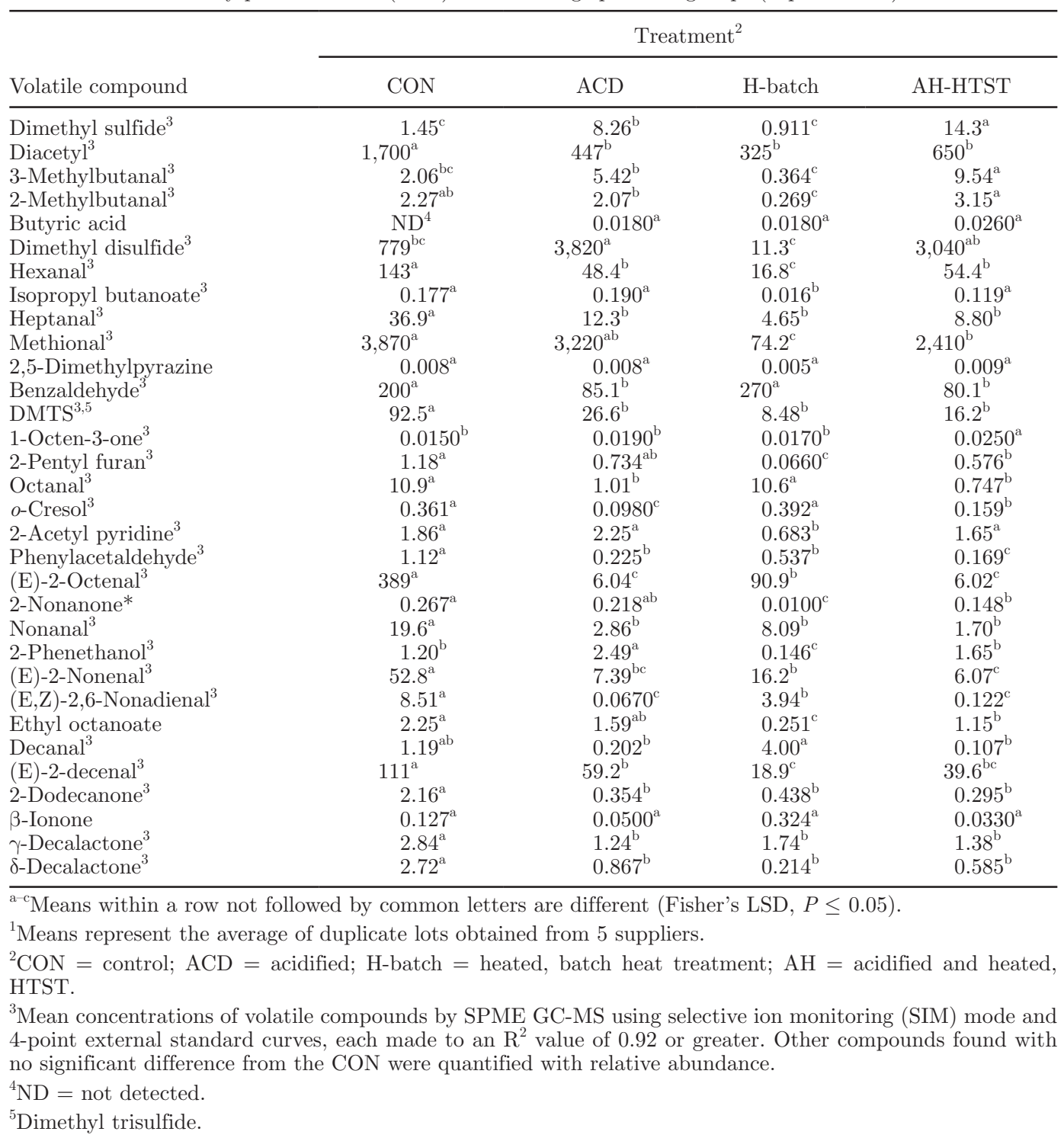

DMDS) are formed from the degradation of methionine into DMS and methanethiol. These compounds can further degrade into DMDS and DMTS (Bendall, 2001). 2-Phenethanol was first identified in dried whey proteins by Carunchia Whetstine et al. (2005). Similar to the formation of DMS and DMDS, 2-phenethanol is formed from the Strecker degradation of the amino acid phenylalanine (Singh et al., 2003; Carunchia Whetstine et al., 2005) and contributes rosy/unclean flavors to whey protein hydrolysate, cheese, and sweet whey powder (Yvon and Rijnen, 2001; Mahajan et al., 2004; Leksrisompong et al., 2010).

All H-batch WPI were characterized by higher intensities of cooked/sulfur flavors (Table 3). Cooked/ sulfur flavors previously reported in dried whey ingre- dients, have been attributed to degradation of sulfurcontaining amino acids (Lee et al., 1996b). However volatile analysis showed that concentrations of DMS and DMDS were not different compared with the CON, whereas concentrations of methional and DMTS decreased (Table 4). This discrepancy, as well as reported decreases in most volatiles, could be explained by the denaturation of WPI protein. Denaturing the whey protein $\left(60-70^{\circ} \mathrm{C}\right)$ will lead to increased proteinprotein interactions (Kühn et al., 2006; Kapoor and Metzger, 2008) and allow the release of hydrophobic odor compounds that were once bound in the native protein configuration. In contrast, protein configuration changes may make more binding sites available to trap and retain compounds such as ethyl hexanoate 
and 2-nonanone (Kühn et al., 2006; Gierczynski et al., 2007). Weel et al. (2003) concluded that the presence of whey protein, however, did not cause retention of aldehydes in vivo and that less binding occurred than what they observed using static GC-MS. Although sulfur compounds were detected in vivo by sensory panelists, it is likely that the batch heat treatment denatured the WPI protein and caused hydrophobic binding of several volatile compounds that were not readily detected by GC-MS. It is also possible that other highly volatile and aroma-active sulfur compounds, such as hydrogen sulfide, were detected by sensory panelists. Due to the low molecular weight and high volatility of such compounds, they have a large effect on flavor but are not readily detected by GC-MS.

Ultimately, manufacturers must use a combination of acidification and heat treatment to stabilize protein beverages. The AH-HTST WPI had high intensities of cardboard, potato/brothy, soapy, and malty flavors (Table 3). By volatile compound analysis, AH-HTST WPI had higher concentrations of 1-octen-3-one compared with the corresponding C WPI $(P \leq 0.05$; Table $4)$. This compound, caused by the autoxidation of lipids, has been linked to off-flavors in oxidized dairy products (Morr and Ha, 1991; Whitson et al., 2010). The combination of acidification and heating may oxidize the WPI to a greater extent than what was observed with the individual steps of acidification and heating. The AH-HTST WPI also had higher concentrations of both 2- and 3-methyl butanal, which are known to contribute potato/brothy and malty flavors (Jansky, 2010). The degradation of amino acids isoleucine and leucine forms compounds 2-methyl butanal and 3-methyl butanal, respectively (Yvon and Rijnen, 2001). Additionally, AH-HTST WPI were higher than the CON in DMS but lower in most other volatiles. Similar to the H-batch WPI, protein denaturation and volatile binding may explain these trends.

\section{Experiment 2. Effect of Lecithin on WPI Flavor After Beverage-Processing Steps}

Descriptive Analysis. Descriptive sensory results reiterated the large effect of beverage-processing steps on WPI flavor observed in experiment 1: increased cardboard, sulfur, and soapy flavors (Table 5). The greatest impact on WPI flavor was the contribution of the various processing treatments, rather than instantization (Figure 1). A closer look at the effect of agglomeration on WPI flavor, however, revealed lecithin as a potential source of grainy, grassy/hay, and cucumber flavors (Table 5). Both CON-INST and ACD-INST WPI had cucumber flavors not observed in the H-INST-batch or
AH-INST-HTST samples. Cucumber flavor has previously been attributed to lecithin oxidation products in WPI and WPC80 (Wright et al., 2009).

No significant differences were observed after heating NI and INST WPI; both were characterized by high overall aroma and sulfur intensities. The thermal degradation and release of sulfur-containing volatiles had an effect on WPI flavor after the heat treatment, perhaps overwhelming the effect of lecithin. Similar to experiment 1, protein degradation of sulfur-containing amino acids likely contributed to these flavors. Acidification and heating steps promoted grainy and grassy/ hay flavors in AH-INST-HTST WPI. Grainy and grassy flavors were not observed before or after processing any of the NI samples. Bread-like notes were previously documented in fermented milk and Cheddar cheese that contained lecithin (Drake et al., 1998; Suriyaphan et al., 2001). The fermented milk and Cheddar cheese were both subjected to subsequent heat treatment after the addition of lecithin, suggesting the effect of thermal processing in the formation of grainy flavors. Suriyaphan et al. (2001) also noted hay/grassy notes in the commercial lecithin before it was included in fermented milk.

$\boldsymbol{G} \boldsymbol{C}$ - $\boldsymbol{M} \boldsymbol{S}$. In the control and after acidification, CON-INST and ACD-INST WPI were higher than their NI counterparts in E-2-nonenal $(P \leq 0.05$; Table $6)$; an autoxidation product of linoleic FA known to contribute cucumber/fatty flavors in instantized dairy products (Drake et al., 2009; Wright et al., 2009; Burdock, 2010). This result was expected, as INST WPI contained approximately 5 times more linoleic acid than NI WPI (Table 2) and soy lecithin is abundant in this FA (Schneider, 1989). Linoleic acid is a precursor for (Z)-3-nonenal, which becomes (E)-2-nonenal after shifting of a double bond (Hoffmann, 1962). Additionally, CON-INST was higher than CON-NI in DMDS, 2-phenethanol, and (E,Z)-2,6-nonadienal $(P \leq 0.05$; Table 6). Both DMDS and 2-phenethanol are formed from the degradation of amino acids methionine and phenylalanine, respectively, and are known contributors of sulfur, brothy, and unclean notes to WPI (Carunchia Whetstine et al., 2005). (E,Z)-2,6-Nonadienal is a lipid oxidation compound previously documented in dried whey ingredients with storage and agglomeration (Carunchia Whetstine et al., 2005; Wright et al., 2009). In addition to differences in (E)-2-nonenal, ACS-INST WPI was lower in furaneol, and $\gamma$-octalactone but higher than ACD-NI in 2-phenethanol. Furaneol and $\gamma$-octalactone contribute sweet aromatic notes to WPI (Carunchia Whetstine et al., 2005). As observed with CON-INST, 2-phenethanol was higher in ACD-INST WPI. However, the increase in concentration from 


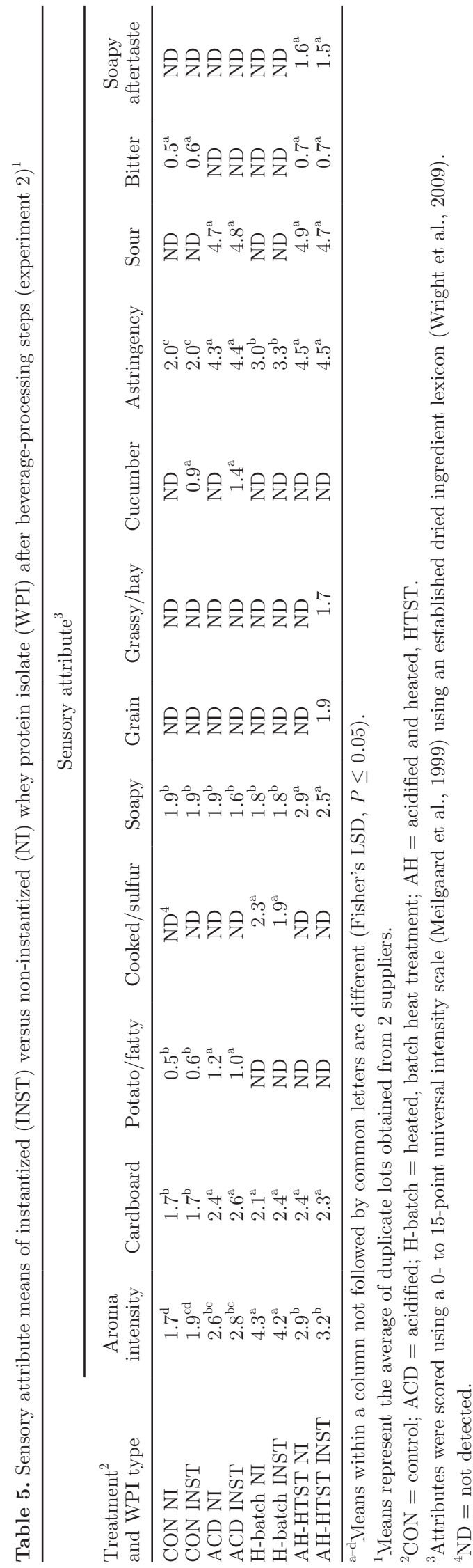

the CON suggests that the acidification step further promoted the formation of this protein degradation compound.

After heating, INST and NI WPI were not perceived as different by sensory analysis (Table 5), but INST WPI were higher in (E)-2-nonenal and (E)-2-dodecenal $(P \leq 0.05$; Table 6$)$. To our knowledge, (E)-2-dodecenal has never been documented in WPI, but is purported to contribute rancid oil and fatty notes to beef and olive oil after heat induced oxidation (Kanavouras and Hernandez, 2006; Resconi et al., 2012). (E)-2-Dodecenal is a compound in the essential oils extracted from seeds and plants (Singh et al., 2008; Deterre et al., 2011).

The acidification and heating on instant WPI resulted in grassy/hay and grainy flavors (Table 5). The AH-INST-HTST WPI were higher in methanethiol, (E,E)-3,5-octadien-2-one, and 2-phenethanol $(P \leq 0.05$; Table 6 ), which are perceived as sulfurous, grassy/hay, and honey/yeasty, respectively (Burdock, 2010). The grassy/hay note detected in AH-INST-HTST could be contributed by the presence of 3,5-octadien-2-one, a known derivative of linoleic oxidation (Burdock, 2010). This compound may originate in lecithin, as Suriyaphan et al. (2001) noted hay/grassy notes in commercial lecithin before addition to milk. However, this compound only increased between AH-NI-HTST and AH-INST-HTST WPI, suggesting that the combination of acidification and heating of WPI promoted lipid oxidation to a higher extent than the individual beverage processing steps alone. This is in congruence with experiment 1: the documented increase of oxidation compound 1-octen-3-one in only AH-HTST WPI. The grainy flavor observed in AH-INST-HTST WPI could be contributed by 2-phenethanol (Burdock, 2010). A bread-like attribute was detected in cheese and fermented milks to which lecithin had been added (Drake et al., 1998; Suriyaphan et al., 2001) and this was attributed to increases in (E,E)-2,4-decadienal (Suriyaphan et al., 1999). However, this compound was not different between corresponding INST and NI WPI. Therefore, more research is needed to verify a direct link between these compounds and the attributes observed in AH-HTST WPI.

Flavor and volatile compound differences observed in the different beverage processing treatments (Figure 1) may be due to conformational changes to WPI proteins $\beta$-LG and $\alpha$-LA. At $\mathrm{pH} 3.0, \alpha$-LA transforms from its native state to an acidic conformation or molten globular state. Contrastingly, at neutral $\mathrm{pH}, \alpha$-LA contains $\mathrm{Ca}^{2+}$ within a high-affinity binding site (Permyakov et al., 1985; Hunt and Dalgleish, 1994). As the $\mathrm{pH}$ is lowered, calcium dissociates, $\beta$-carboxyl groups become protonated and approximately half the hydrophobic domains become exposed (Permyakov et al., 1985; 


\section{PCA Biplot (67\%)}

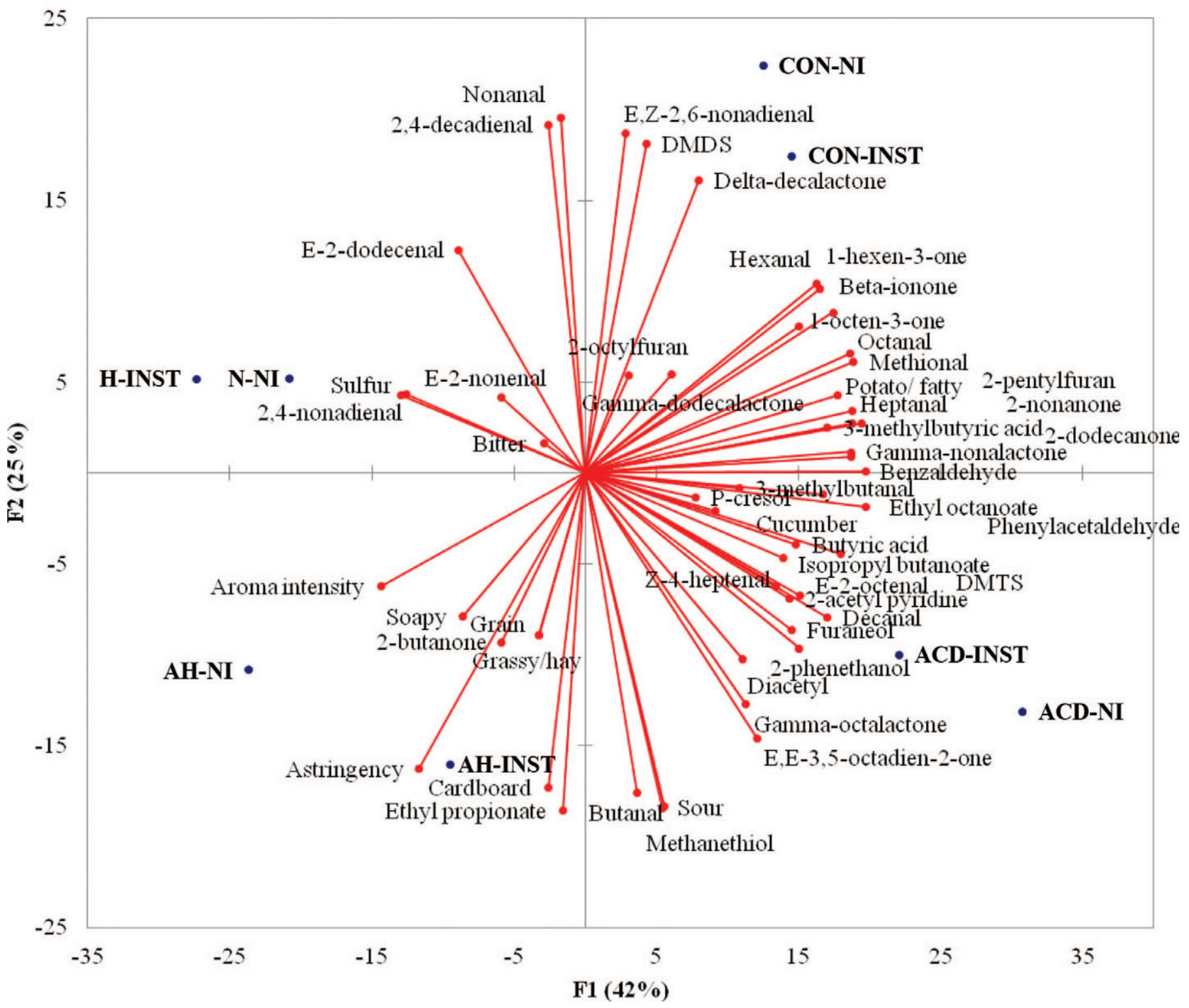

Figure 1. Principal components analysis (PCA) biplot of factor 1 (F1) and factor 2 (F2) of all sensory attributes and volatile compounds detected in non-instantized and instantized whey protein isolate (WPI) before and after processing (experiment 2$)$. CON $=$ control; $\mathrm{ACD}=$ acidified; $\mathrm{H}=$ heated-batch heat treatment; $\mathrm{AH}=$ acidified and heated, HTST; INST = instantized; NI = not instantized; DMDS = dimethyl disulfide; DMTS = dimethyl trisulfide. Color version available in the online PDF.

Hunt and Dalgleish, 1994). Parts of the protein, now available, can interact with other lipids, sugars, and proteins within the system to produce volatiles. This could help to explain how the amino acid degradation products DMS, DMDS, and 2-phenethanol (Table 4) increased in ACD WPI. 2-Phenethanol was higher in ACD-INST than ACD-NI WPI (Table 6), suggesting greater susceptibility of instant WPI to protein degradation. Yasosky et al. (1984) theorized that when histidine residues were ionized [logarithmic constant $(\mathrm{pKa})<6.0$ ] at a low $\mathrm{pH}$, the protein's net charge or tertiary structure (or both) was altered and reduced the protein's ability to sequester catalytic ions, including $\mathrm{Mn}, \mathrm{Cu}, \mathrm{Co}$, and $\mathrm{Fe}$. The metal ions can then activate oxygen and initiate lipid oxidation of unsaturated FA found in the WPI. Instant WPI contained higher concentrations of unsaturated FA and this mechanism may explain the increased concentration of (E)-2-nonenal in ACD-INST WPI (Table 6).

Whey proteins can also denature from thermal processing. Both $\beta$-LG and $\alpha$-LA are stabilized by intramolecular disulfide bonds in their native globular state 
Table 6. Concentration ( $\mu \mathrm{g} / \mathrm{kg}$ ) of selected compounds in instantized (INST) and non-instantized (NI) whey protein isolate (WPI) by solidphase microextraction (SPME) GC-MS (experiment 2) ${ }^{1}$

\begin{tabular}{|c|c|c|c|c|c|c|c|c|}
\hline \multirow[b]{2}{*}{ Compound } & \multicolumn{8}{|c|}{ Treatment and WPI type ${ }^{2}$} \\
\hline & $\mathrm{CON}-\mathrm{NI}$ & CON-INST & ACD-NI & ACD-INST & H-NI batch & $\begin{array}{l}\text { H-INST } \\
\text { batch }\end{array}$ & $\begin{array}{l}\text { AH-NI } \\
\text { HTST }\end{array}$ & $\begin{array}{l}\text { AH-INST } \\
\text { HTST }\end{array}$ \\
\hline Methanethiol (TID) $)^{3,4}$ & $1.26^{\mathrm{c}}$ & $0.930^{\mathrm{c}}$ & $14.6^{\mathrm{a}}$ & $16.6^{\mathrm{a}}$ & $4.40^{\mathrm{b}}$ & $6.64^{\mathrm{b}}$ & $8.42^{\mathrm{b}}$ & $13.6^{\mathrm{a}}$ \\
\hline 2-Butanone & $0.0474^{\mathrm{a}}$ & $0.346^{\mathrm{abc}}$ & $0.160^{\mathrm{bc}}$ & $0.159^{\mathrm{bc}}$ & $0.122^{\mathrm{c}}$ & $0.152^{\mathrm{bc}}$ & $0.475^{\mathrm{a}}$ & $0.461^{\mathrm{ab}}$ \\
\hline Butanal & $1.37^{\mathrm{b}}$ & $1.53^{\mathrm{ab}}$ & $1.63^{\mathrm{a}}$ & $1.58^{\mathrm{ab}}$ & $1.47^{\mathrm{ab}}$ & $1.51^{\mathrm{ab}}$ & $1.57^{\mathrm{ab}}$ & $1.62^{\mathrm{a}}$ \\
\hline Diacetyl & $0.0610^{\mathrm{b}}$ & $0.0670^{\mathrm{ab}}$ & $0.0750^{\mathrm{ab}}$ & $0.0840^{\mathrm{a}}$ & $0.0730^{\mathrm{ab}}$ & $0.0570^{\mathrm{b}}$ & $0.0640^{\mathrm{b}}$ & $0.0700^{\mathrm{ab}}$ \\
\hline 3-Methylbutanal & $4.22^{\mathrm{a}}$ & $5.14^{\mathrm{a}}$ & $4.78^{\mathrm{a}}$ & $4.56^{\mathrm{a}}$ & $3.92^{\mathrm{a}}$ & $4.44^{\mathrm{a}}$ & $4.42^{\mathrm{a}}$ & $4.48^{\mathrm{a}}$ \\
\hline Ethyl propionate & $\mathrm{ND}^{5}$ & ND & $0.0700^{\mathrm{a}}$ & $0.0690^{\mathrm{a}}$ & $0.0560^{\mathrm{ab}}$ & $0.0410^{\mathrm{b}}$ & $0.0570^{\mathrm{ab}}$ & $0.0620^{\mathrm{ab}}$ \\
\hline Butyric acid & $0.0150^{\mathrm{a}}$ & $0.0150^{\mathrm{a}}$ & $0.0160^{\mathrm{a}}$ & $0.0160^{\mathrm{a}}$ & $0.005^{\mathrm{b}}$ & $0.005^{\mathrm{b}}$ & $0.0150^{\mathrm{a}}$ & $0.0130^{\mathrm{a}}$ \\
\hline 1-Hexen-3-one & $0.0390^{\mathrm{a}}$ & $0.0390^{\mathrm{a}}$ & $0.0370^{\mathrm{a}}$ & $0.0360^{\mathrm{a}}$ & $0.0300^{\mathrm{ab}}$ & $0.0300^{\mathrm{ab}}$ & $0.0220^{\mathrm{b}}$ & $0.0280^{\mathrm{ab}}$ \\
\hline $\mathrm{DMDS}^{3,6}$ & $2.15^{\mathrm{b}}$ & $2.86^{\mathrm{a}}$ & $1.13^{\mathrm{d}}$ & $1.36^{\mathrm{cd}}$ & $1.85^{\mathrm{bc}}$ & $1.75^{\mathrm{bc}}$ & $0.557^{\mathrm{e}}$ & $0.601^{\mathrm{e}}$ \\
\hline Hexanal & $1.93^{\mathrm{a}}$ & $1.63^{\mathrm{ab}}$ & $1.24^{\mathrm{abcd}}$ & $1.41^{\mathrm{abc}}$ & $0.503^{\mathrm{cd}}$ & $0.452^{\mathrm{d}}$ & $0.454^{\mathrm{d}}$ & $0.658^{\mathrm{bcd}}$ \\
\hline 3-Methylbutyric acid & $0.007^{\mathrm{a}}$ & $0.007^{\mathrm{a}}$ & $0.006^{\mathrm{ab}}$ & $0.006^{\mathrm{ab}}$ & ND & ND & ND & $0.006^{\mathrm{ab}}$ \\
\hline Isopropyl butanoate & $0.110^{\mathrm{a}}$ & $0.131^{\mathrm{a}}$ & $0.158^{\mathrm{a}}$ & $0.117^{\mathrm{a}}$ & $0.031^{\mathrm{b}}$ & $0.009^{\mathrm{b}}$ & $0.0140^{\mathrm{b}}$ & $0.200^{\mathrm{b}}$ \\
\hline Methional & $7.74^{\mathrm{a}}$ & $7.96^{\mathrm{a}}$ & $7.31^{\mathrm{a}}$ & $7.01^{\mathrm{a}}$ & $0.690^{\mathrm{cd}}$ & $0.0250^{\mathrm{d}}$ & $1.00^{\mathrm{bc}}$ & $1.57^{\mathrm{b}}$ \\
\hline (Z)-4-Heptenal & $0.189^{\mathrm{b}}$ & $0.094^{\mathrm{b}}$ & $0.418^{\mathrm{a}}$ & $0.270^{\mathrm{ab}}$ & $0.238^{\mathrm{ab}}$ & $0.0970^{\mathrm{b}}$ & $0.0990^{\mathrm{b}}$ & $0.118^{\mathrm{b}}$ \\
\hline Heptanal & $0.750^{\mathrm{a}}$ & $0.559^{\mathrm{ab}}$ & $0.750^{\mathrm{a}}$ & $0.630^{\mathrm{a}}$ & $0.291^{\mathrm{c}}$ & $0.226^{\mathrm{c}}$ & $0.361^{\mathrm{bc}}$ & $0.332^{\mathrm{bc}}$ \\
\hline Benzaldehyde & $1.29^{\mathrm{abc}}$ & $1.59^{\mathrm{ab}}$ & $1.78^{\mathrm{a}}$ & $1.64^{\mathrm{ab}}$ & $0.378^{\mathrm{c}}$ & $0.403^{\mathrm{c}}$ & $0.619^{\mathrm{bc}}$ & $0.844^{\mathrm{abc}}$ \\
\hline $\operatorname{DMTS}^{7}$ & $0.115^{b c}$ & $0.231^{\mathrm{ab}}$ & $0.349^{\mathrm{a}}$ & $0.320^{\mathrm{a}}$ & $0.0720^{\mathrm{c}}$ & $0.0700^{\mathrm{c}}$ & $0.0880^{\mathrm{bc}}$ & $0.0750^{\mathrm{bc}}$ \\
\hline 1-Octen-3-one & $0.111^{\mathrm{abc}}$ & $0.130^{\mathrm{a}}$ & $0.0900^{\mathrm{abc}}$ & $0.127^{\mathrm{ab}}$ & $0.0760^{\mathrm{bcd}}$ & $0.0640^{\mathrm{cd}}$ & $0.0270^{\mathrm{d}}$ & $0.0810^{\mathrm{abcd}}$ \\
\hline 2-Pentylfuran & $4.27^{\mathrm{a}}$ & $4.09^{\mathrm{a}}$ & $4.16^{\mathrm{a}}$ & $4.12^{\mathrm{a}}$ & $2.55^{\mathrm{a}}$ & $1.61^{\mathrm{a}}$ & $2.67^{\mathrm{a}}$ & $3.07^{\mathrm{a}}$ \\
\hline Octanal & $0.461^{\mathrm{a}}$ & $0.417^{\mathrm{a}}$ & $0.456^{\mathrm{a}}$ & $0.376^{\mathrm{ab}}$ & $0.260^{\mathrm{c}}$ & $0.141^{\mathrm{c}}$ & $0.181^{\mathrm{c}}$ & $0.224^{\mathrm{bc}}$ \\
\hline Phenylacetaldehyde & $0.0610^{\mathrm{ab}}$ & $0.0450^{\mathrm{bc}}$ & $0.0880^{\mathrm{a}}$ & $0.0720^{\mathrm{ab}}$ & $0.0160^{\mathrm{cd}}$ & ND & $0.0170^{\mathrm{cd}}$ & $0.0280^{\mathrm{cd}}$ \\
\hline 2-Acetyl pyridine & ND & $0.0100^{\mathrm{b}}$ & $0.0580^{\mathrm{a}}$ & $0.0110^{\mathrm{b}}$ & ND & ND & ND & ND \\
\hline (E)-2-Octenal & $0.985^{\mathrm{b}}$ & $3.80^{\mathrm{ab}}$ & $8.19^{\mathrm{a}}$ & $3.15^{\mathrm{ab}}$ & $0.481^{\mathrm{b}}$ & $1.79^{\mathrm{b}}$ & $0.846^{\mathrm{b}}$ & $2.28^{\mathrm{b}}$ \\
\hline Furaneol $^{3}$ & $1,430^{\mathrm{b}}$ & $6,010^{\mathrm{b}}$ & $20,700^{\mathrm{a}}$ & $6,860^{\mathrm{b}}$ & $686^{\mathrm{b}}$ & $2,860^{\mathrm{b}}$ & $1,610^{\mathrm{b}}$ & $4,990^{\mathrm{b}}$ \\
\hline $\begin{array}{l}(\mathrm{E}, \mathrm{E})-3,5-O c t a d i e n-2-o n e \\
(\mathrm{TID})^{3,4}\end{array}$ & ND & ND & $5.78^{\mathrm{a}}$ & $2.81^{\mathrm{bc}}$ & ND & ND & $0.396^{\mathrm{cd}}$ & $3.35^{\mathrm{ab}}$ \\
\hline 2-Nonanone & $1.54^{\mathrm{a}}$ & $1.58^{\mathrm{a}}$ & $1.71^{\mathrm{a}}$ & $1.57^{\mathrm{a}}$ & $0.111^{\mathrm{b}}$ & $0.0900^{\mathrm{b}}$ & $0.464^{\mathrm{b}}$ & $0.605^{\mathrm{b}}$ \\
\hline p-Cresol & ND & $0.009^{\mathrm{a}}$ & ND & $0.009^{\mathrm{a}}$ & ND & ND & ND & $0.006^{\mathrm{b}}$ \\
\hline Nonanal $^{3}$ & $52.2^{\mathrm{a}}$ & $43.3^{\mathrm{b}}$ & $11.7^{\mathrm{d}}$ & $7.61^{\mathrm{d}}$ & $34.7^{\mathrm{c}}$ & $39.5^{\mathrm{bc}}$ & $6.62^{\mathrm{d}}$ & $7.13^{\mathrm{d}}$ \\
\hline 2-Phenethanol ${ }^{3}$ & $0.428^{\mathrm{d}}$ & $0.964^{\mathrm{c}}$ & $1.62^{\mathrm{b}}$ & $2.49^{\mathrm{a}}$ & $0.205^{\mathrm{d}}$ & $0.206^{\mathrm{d}}$ & $0.440^{\mathrm{b}}$ & $1.03^{\mathrm{c}}$ \\
\hline (E)-2-Nonenal ${ }^{3}$ & $7.71^{\text {de }}$ & $25.7^{\mathrm{bc}}$ & $16.1^{\mathrm{cd}}$ & $27.5^{\mathrm{b}}$ & $23.4^{\mathrm{bc}}$ & $62.4^{\mathrm{a}}$ & $5.31^{\mathrm{e}}$ & $7.90^{\text {de }}$ \\
\hline$(\mathrm{E}, \mathrm{Z})-2,6-$ Nonadienal $^{3}$ & $33.7^{\mathrm{b}}$ & $45.7^{\mathrm{a}}$ & $0.394^{\mathrm{e}}$ & $0.577^{\mathrm{e}}$ & $10.6^{\mathrm{cd}}$ & $15.8^{\mathrm{c}}$ & $0.174^{\mathrm{e}}$ & $0.706^{\mathrm{de}}$ \\
\hline Ethyl octanoate & $0.877^{\mathrm{bc}}$ & $0.884^{\mathrm{bc}}$ & $1.56^{\mathrm{a}}$ & $1.25^{\mathrm{ab}}$ & $0.947^{\mathrm{bc}}$ & $0.564^{\mathrm{cd}}$ & $0.204^{\mathrm{d}}$ & $0.616^{\mathrm{cd}}$ \\
\hline Decanal & $0.308^{c}$ & $0.309^{\mathrm{c}}$ & $0.621^{\mathrm{a}}$ & $0.515^{\mathrm{ab}}$ & $0.268^{\mathrm{c}}$ & $0.252^{\mathrm{c}}$ & $0.197^{\mathrm{c}}$ & $0.327^{\mathrm{bc}}$ \\
\hline 2,4-Nonadienal & $0.018^{\mathrm{bc}}$ & $0.008^{\mathrm{cd}}$ & $0.0320^{\mathrm{a}}$ & $0.0230^{\mathrm{ab}}$ & ND & ND & $0.009^{\mathrm{cd}}$ & $0.0150^{\mathrm{bc}}$ \\
\hline 2-Octylfuran (TID) ${ }^{4}$ & ND & $0.008^{\mathrm{a}}$ & ND & $0.007^{\mathrm{a}}$ & ND & $0.006^{\mathrm{ab}}$ & ND & ND \\
\hline$\gamma$-Octalactone ${ }^{3}$ & $0.0953^{\mathrm{c}}$ & $0.113^{\mathrm{c}}$ & $0.526^{\mathrm{a}}$ & $0.342^{\mathrm{b}}$ & $0.199^{\mathrm{bc}}$ & $0.194^{\mathrm{bc}}$ & $0.112^{\mathrm{c}}$ & $0.247^{\mathrm{bc}}$ \\
\hline 2,4-Decadienal ${ }^{3}$ & $10.7^{\mathrm{a}}$ & $9.13^{\mathrm{ab}}$ & $0.0363^{\mathrm{c}}$ & $0.0221^{\mathrm{c}}$ & $9.49^{\mathrm{ab}}$ & $5.91^{\mathrm{b}}$ & $0.0158^{\mathrm{c}}$ & $0.0151^{\mathrm{c}}$ \\
\hline$\gamma$-Nonalactone & $0.133^{\mathrm{ab}}$ & $0.106^{\mathrm{abc}}$ & $0.164^{\mathrm{a}}$ & $0.122^{\mathrm{ab}}$ & $0.0920^{\mathrm{bc}}$ & $0.0550^{\mathrm{c}}$ & $0.0520^{\mathrm{c}}$ & $0.0870^{\mathrm{bc}}$ \\
\hline 2-Dodecanone & $0.724^{\mathrm{ab}}$ & $0.559^{\mathrm{abc}}$ & $1.02^{\mathrm{a}}$ & $0.652^{\mathrm{ab}}$ & $0.392^{\mathrm{bc}}$ & $0.133^{c}$ & $0.288^{\mathrm{bc}}$ & $0.259^{\mathrm{bc}}$ \\
\hline (E)-2-Dodecenal ${ }^{3}$ & $14.6^{\mathrm{bc}}$ & $23.6^{\mathrm{b}}$ & $0.772^{\mathrm{c}}$ & $0.417^{\mathrm{c}}$ & $17.9^{\mathrm{b}}$ & $48.2^{\mathrm{a}}$ & $0.261^{\mathrm{c}}$ & $0.222^{\mathrm{c}}$ \\
\hline$\beta$-Ionone & $0.0200^{\mathrm{a}}$ & $0.0150^{\mathrm{ab}}$ & $0.0180^{\mathrm{ab}}$ & $0.0130^{\mathrm{b}}$ & $0.007^{\mathrm{c}}$ & $0.005^{\mathrm{c}}$ & ND & $0.005^{\mathrm{c}}$ \\
\hline$\delta$-Decalactone & $0.139^{\mathrm{a}}$ & $0.0820^{\mathrm{ab}}$ & $0.0180^{\mathrm{b}}$ & $0.0130^{\mathrm{b}}$ & $0.008^{\mathrm{b}}$ & $0.005^{\mathrm{b}}$ & $0.009^{\mathrm{b}}$ & $0.007^{\mathrm{b}}$ \\
\hline$\gamma$-Dodecalactone & $0.005^{\mathrm{a}}$ & ND & $0.005^{\mathrm{a}}$ & ND & $0.005^{\mathrm{a}}$ & ND & ND & ND \\
\hline
\end{tabular}

${ }^{a-e}$ Means within a row not followed by common letters are different (Fisher's LSD, $P \leq 0.05$ ).

${ }^{1}$ Means represent the average of duplicate lots obtained from 2 suppliers.

${ }^{2} \mathrm{CON}=$ control; $\mathrm{ACD}=$ acidified; H-batch $=$ heated, batch heat treatment; $\mathrm{AH}=$ acidified and heated, HTST.

${ }^{3}$ Mean concentrations of volatile compounds by SPME GC-MS using selective ion monitoring (SIM) mode and 4-point external standard curves; each made to an $\mathrm{R}^{2}$ value of 0.92 or greater. Otherwise, means quantified with relative abundance as differences between INST and NI within a treatment were not documented.

${ }^{4} \mathrm{TID}=$ compound tentatively identified based on retention index, published literature, and odor property by gas chromatography olfactometry; standard curve made with dimethyl sulfide (DMS; replaced methanethiol) and 2,5-octanedione [replaced (E,E)-3,5-octadien-2-one].

${ }^{5} \mathrm{ND}=$ not detected.

${ }^{6}$ Dimethyl disulfide.

${ }^{7}$ Dimethyl trisulfide.

(2 and 4 bonds, respectively; Monahan et al., 1995). The protein $\beta$-LG also has a free sulfhydryl group. When the native whey protein structure is destroyed, the unfolding protein creates interactions between proteins, including thiol/thiol oxidation reactions and thiol/disulfide interchanges. Once heated, $\beta$-LG forms sulfhydryl-reducing compounds, which contribute to cooked and sulfur flavors in dairy products. Hydrogen 
sulfide is very odor active, inducing a sensory response at low concentrations; however, this compound is almost impossible to detect with instrumental analyses. These sulfhydryl-reducing compounds may be responsible for the cooked/sulfur flavor found in both the H-NI and H-INST WPI.

The combination of heating and acidification can have a collective effect on protein denaturation and volatile formation, and this result was suggested by sensory analysis in the current study, as higher potato or soapy flavors, or both, were documented in AH-HTST WPI in contrast to ACD or H-batch WPI. For example, $\beta$-LG does not denature even at a pH as low as 2.0 (Casal et al., 1988). However, the combination of low $\mathrm{pH}$ and thermal treatment can affect the native conformation of the globular protein. Beginning at $60^{\circ} \mathrm{C}$, the $\alpha$-helices and exposed $\beta$-sheets begin to unfold in the first stage of heat denaturation; the second stage begins around $90^{\circ} \mathrm{C}$, in which the rest of the strands unfold (Casal et al., 1988). When $\alpha$-LA is heated at neutral $\mathrm{pH}$, high temperatures are necessary for the protein to completely unfold. However, at low $\mathrm{pH}$, lower temperatures are needed, and the protein enters a more intermediate compact denatured state (the molten globule state). Between pH 3.5 and 3.0, between 80 and $100 \%$ of the protein immediately transforms into the compact intermediate state upon heat denaturation (Griko et al., 1994). Additionally, lipid degradation can be catalyzed by both acidic conditions and thermal treatment (Frankel, 1998). This may explain the differences in lipid oxidation compounds [1-octen-3-one (Table 4) observed in AH-HTST WPI and 3,5-octadien-2-one (Table 6) observed in AH-INST-HTST WPI]. Instant WPI contained higher concentrations of unsaturated FA and, therefore, is more susceptible to oxidation.

Instantization of WPI with soy lecithin affects WPI flavor and flavor stability. This effect has been previously documented by Wright et al. (2009) and our results confirm this initial effect on flavor. Results from the current study also suggest that soy lecithin may also contribute additional flavors in beverage processing. The use of alternative wetting agents or steam agglomeration may counterbalance these effects. However, beverage manufacturing steps had large effects on whey protein flavor, regardless of instantization. These effects may be minimized by complementary ingredients within the beverages to remove, lessen, or mask the off-flavors of treated WPI. Additionally, future research is needed to optimize processing treatments for product functionality and flavor. Acidification of WPI before instantization and drying steps may volatilize flavor compounds, release them from the matrix, and create better-flavored WPI ingredients for beverage applications.

\section{CONCLUSIONS}

The postprocessing treatments of acidification and heating negatively affected the flavor of NI WPI. Acidification increased concentrations of DMS, DMDS, and 2-phenethanol, while enhancing potato/brothy and cardboard flavors. Heating the WPI increased perceived cooked/sulfur flavors. The combination of acidification and heating promoted the formation of 3-methyl butanal, 2-methyl butanal, 1-octen-3-one, cardboard, soapy, potato/brothy, and malty flavors. Beverage unit operations had a larger effect on the flavor contributions of WPI than instantization, but the use of INST WPI contributed flavors as well. Cucumber flavor and higher concentrations of (E)-2-nonenal and 2-phenethanol were documented in instantized acidified WPI. Additionally, grainy and grassy/hay flavors, methanethiol, (E,E)-3,5octadien-2-one, and 2-phenethanol were higher in instant WPI after AH-HTST beverage-processing steps. These undesirable flavors can carry over into ingredient applications, presenting a challenge to manufacturers. Further research is necessary to discover alternative processing treatments, alternative forms of lecithin, and complementary ingredients to remove, lessen, or mask the flavors contributed by postprocessing of WPI.

\section{ACKNOWLEDGMENTS}

Funding was provided by the Dairy Research Institute (Rosemont, IL). The use of trade names does not imply endorsement or lack of endorsement by those not mentioned.

\section{REFERENCES}

Adda, J., J. C. Gripon, and L. Vassal. 1982. The chemistry of flavour and texture generation in cheese. Food Chem. 9:115-129.

AOAC International. 2000. Official Methods of Analysis. 17th ed. AOAC International, Gaithersburg, MD.

Bendall, J. G. 2001. Aroma compounds of fresh milk from New Zealand cows fed different diets. J. Agric. Food Chem. 49:4825-4832.

Burdock, G. A. 2010. Fenaroli's Handbook of Flavor Ingredients. 6th ed. Taylor and Francis Group, Boca Raton, FL.

Carunchia Whetstine, M. E., A. E. Croissant, and M. A. Drake. 2005. Characterization of dried whey protein concentrate and isolate flavor. J. Dairy Sci. 88:3826-3839.

Carunchia Whetstine, M. E., J. D. Parker, M. A. Drake, and D. K. Larick. 2003. Determining flavor and flavor variability in commercially produced liquid cheddar whey. J. Dairy Sci. 86:439-448.

Casal, H. L., U. Köhler, and H. M. Mantsch. 1988. Structural and conformational changes of $\beta$-lactoglobulin B: An infrared spectroscopic study of the effect of $\mathrm{pH}$ and temperature. Biochim. Biophys. Acta 957:11-20.

Childs, J. L., M. D. Yates, and M. A. Drake. 2007. Sensory properties of meal replacement bars and beverages made from whey and soy proteins. J. Food Sci. 72:S425-S434.

Colbert, L. B. 1998. Lecithins tailored to your emulsification needs. Cereal Foods World 43:686-688.

Cole, M. B., and M. V. Jones. 1990. A submerged-coil heating apparatus for investigating thermal inactivation of microorganisms. Lett. Appl. Microbiol. 11:233-235. 
Croissant, A. E., E. J. Kang, R. E. Campbell, E. Bastian, and M. A Drake. 2009. The effect of bleaching agent on the flavor of liquid whey and whey protein concentrate. J. Dairy Sci. 92:5917-5927.

Deterre, S., B. Rega, J. Delarue, M. Decloux, M. Lebrun, and P. Giampaoli. 2011. Identification of key aroma compounds from bitter orange (Citrus aurantium L.) products: Essential oil and maceratedistillate extract. Flavour Fragrance J. 27:77-88.

Drake, M. A. 2006. Flavor and flavor carry-through of whey proteins in beverages. Pages 292-300 in The Wonders of Whey . . Catch the Power. Proc. 4th Intl. Whey Conference. American Dairy Products Institute, Elmhurst, IL.

Drake, M. A., X. Q. Chen, P. D. Gerard, and S. U. Gurkin. 1998. Composition and quality attributes of reduced-fat cheese as affected by lecithin type. J. Food Sci. 63:1018-1023.

Drake, M. A., R. E. Miracle, and J. M. Wright. 2009. Sensory properties of dairy proteins. Pages 429-448 in Milk Proteins: From Expression to Food. A. Thompson, M. Boland, and H. Singh, ed. Elsevier, New York, NY.

Evans, J., J. Zulewska, M. Newbold, M. A. Drake, and D. M. Barbano. 2010. Comparison of composition and sensory properties of $80 \%$ whey protein and milk serum protein concentrates. J. Dairy Sci. 93:1824-1843.

Frankel, E. N. 1998. Lipid Oxidation. The Oily Press, Dundee, Scotland.

Gallardo-Escamilla, F. J., A. L. Kelly, and C. M. Delahunty. 2005. Sensory characteristics and related volatile flavor compound profiles of different types of whey. J. Dairy Sci. 88:2689-2699.

Gierczynski, I., H. Labouré, E. Sémon, and E. Guichard. 2007. Impact of hardness of model fresh cheese on aroma release: In vivo and in vitro study. J. Agric. Food Chem. 55:3066-3073.

Griko, Y. V., E. Freire, and P. L. Privalov. 1994. Energetics of the $\alpha$-lactalbumin states: A calorimetric and statistical thermodynamic study. Biochemistry 33:1889-1899.

Harwalkar, V. R., H. Cholette, R. C. McKellar, and D. B. Emmons. 1993. Relation between proteolysis and stringent off-flavor in milk. J. Dairy Sci. 76:2521-2527.

Hazen, C. 2003. Food Product Design: Formulating function into beverages. Weeks Publishing Company, Northbrook, IL. Accessed Oct. 15, 2010. http://www.foodproductdesign.com/articles/2003/01/ formulating------function-into-beverages.aspx.

Henning, D. R., R. J. Baer, A. N. Hassan, and R. Dave. 2006. Major advances in concentrated and dry milk products, cheese, and milk fat-based spreads. J. Dairy Sci. 89:1179-1188.

Hoffmann, G. 1962. Vegetable oils. Pages 215-227 in Symposium on Foods: Lipids and Their Oxidation. H. W. Schultz, E. A. Day, and R. O. Sinnhuber, ed. The AVI Publishing Company Inc., Westport, CT.

Holt, C., D. McPhail, I. Nevison, T. Nylander, J. Otte, R. H. Ipsen, R. Bauer, L. Øgendal, K. Olieman, K. G. de Kruif, J. Léonil, D. Mollé, G. Henry, J. L. Maubois, M. D. Pérez, P. Puyol, M. Calvo, S. M. Bury, G. Kontopidis, I. McNae, L. Sawyer, L. Ragona, L. Zetta, H. Molinari, B. Klarenbeek, M. J. Jonkman, J. Moulin, and D. Chatterton. 1999. Apparent chemical composition of nine commercial or semi-commercial whey protein concentrates, isolates, and fractions. Int. J. Food Sci. Technol. 34:543-556.

Hunt, J. A., and D. G. Dalgleish. 1994. Effect of pH on the stability and surface composition of emulsions made with whey protein isolate. J. Agric. Food Chem. 42:2131-2135.

Jansky, S. H. 2010. Potato flavor. Am. J. Potato Res. 87:209-217.

Kanavouras, A., and R. J. Hernandez. 2006. The analysis of volatiles from thermally oxidized virgin olive oil using dynamic sorptionthermal desorption and solid phase micro-extraction techniques. Int. J. Food Sci. Technol. 41:743-750.

Kapoor, R., and L. E. Metzger. 2008. Process cheese: Scientific and technological aspects-A review. Comp. Rev. Food Sci. Food Safety $7: 194-214$.

Kühn, J., T. Considine, and H. Singh. 2006. Interactions of milk proteins and volatile flavor compounds: Implications in the development of protein foods. J. Food Sci. 71:R72-R82.
LaClair, C. E., and M. R. Etzel. 2010. Ingredients and pH are key to clear beverages that contain whey protein. J. Food Sci. 75:C21$\mathrm{C} 27$.

Lee, K. D., C. G. Lo, and J. J. Warthesen. 1996a. Removal of bitterness from the bitter peptides extracted from Cheddar cheese with peptidases from Lactococcus lactis ssp. cremoris SK11. J. Dairy Sci. 79:1521-1528

Lee, Y. B., I. Laye, Y. D. Kim, and C. V. Morr. 1996b. Formation of volatile compounds in whey protein concentrate during elevated temperature storage as a function of water activity. Int. Dairy J. $6: 485-496$.

Leksrisompong, P. P., R. E. Miracle, and M. A. Drake. 2010. Characterization of flavor of whey protein hydrolysates. J. Agric. Food Chem. 58:6318-6327.

Linden, G., and D. Lorient. 1999. The exploitation of by-products. Pages 184-210 in New Ingredients in Food Processing: Biochemistry and Agriculture. G. Linden and D. Lorient, ed. CRC Press, Boca Raton, FL.

Listiyani, M. A. D., R. E. Campbell, R. E. Miracle, L. O. Dean, and M. A. Drake. 2011. Influence of bleaching on flavor of $34 \%$ whey protein concentrate and residual benzoic acid concentration in dried whey proteins. J. Dairy Sci. 94:4347-4359.

Lloyd, M. A., S. J. Hess, and M. A. Drake. 2009. Effect of nitrogen flushing and storage temperature on flavor and shelf-life of whole milk powder. J. Dairy Sci. 92:2409-2422.

Mahajan, S. S., L. Goddik, and M. C. Qian. 2004. Aroma compounds in sweet whey powder. J. Dairy Sci. 87:4057-4063.

Meilgaard, M. C., G. V. Civille, and B. T. Carr. 1999. Sensory evaluation techniques. 3rd ed. CRC Press Inc., Boca Raton, FL.

Monahan, F. J., J. B. German, and J. E. Kinsella. 1995. Effect of pH and temperature on protein unfolding and thiol/disulfide interchange reactions during heat-induced gelation of whey proteins. J. Agric. Food Chem. 43:46-52.

Morr, C. V., and E. Y. W. Ha. 1991. Off-flavors of whey protein concentrates: A literature review. Int. Dairy J. 1:1-11.

Mortenson, M. A., Z. M. Vickers, and G. A. Reineccius. 2008. Flavor of whey protein concentrates and isolates. Int. Dairy J. 18:649-657.

Permyakov, E. A., L. A. Morozova, and E. A. Burstein. 1985. Cation binding effects on the $\mathrm{pH}$, thermal, and urea denaturation transitions in $\alpha$-lactalbumin. Biophys. Chem. 21:21-31.

Prendergast, K. 1985. Whey drinks-Technology, processing and marketing. Int. J. Dairy Technol. 38:103-105.

Resconi, V. C., A. Escudero, J. A. Beltrán, J. L. Olleta, C. Sañudo, and M. del Mar Campo. 2012. Color, lipid oxidation, sensory quality, and aroma compounds of beef steaks displayed under different levels of oxygen in a modified atmosphere package. J. Food Sci. 77:S10-S18.

Rittmanic, S. 2006. U.S. whey proteins in ready-to-drink beverages. Pages 1-8 in Applications Monograph Beverages. US Dairy Export Council, Arlington, VA.

Schneider, M. 1989. Fractionation and purification of lecithin. Pages 109-130 in Lecithins: Sources, Manufacture, and Uses. B. F. Szuhaj, ed. American Oil Chemists' Society, Champaign, IL.

Singh, G. S. Kiran, P. Marimuthu, V. Isidorov, and V. Vinogorova 2008. Antioxidant and antimicrobial activities of essential oil and various oleoresins of Elettaria cardamomum (seeds and pods). J. Sci. Food Agric. 88:280-289.

Singh, T., M. A. Drake, and K. R. Cadwallader. 2003. Flavor of Cheddar cheese: A chemical and sensory perspective. Comp. Rev. Food Sci. Food Safety 2:139-162.

Suriyaphan, O., K. R. Cadwallader, and M. A. Drake. 2001. Lecithin associated off-aromas in fermented milk. Food Chem. Toxicol. $66: 517-523$

Suriyaphan, O., M. A. Drake, and K. R. Cadwallader. 1999. Identification of volatile off-flavors in reduced-fat Cheddar cheeses containing lecithin. Lebensm. Wiss. Technol. 32:250-254.

Tomaino, R. M., J. D. Parker, and D. K. Larick. 2001. Analysis of free fatty acids in whey products by solid-phase microextraction. J. Agric. Food Chem. 49:3993-3998. 
Tomaino, R. M., L. G. Turner, and D. K. Larick. 2004. The effect of Lactococcus lactis starter culture on the oxidative stability of liquid whey. J. Dairy Sci. 87:300-307.

van den Dool, H., and P. D. Kratz. 1963. A generalization of the retention index system including linear temperature programmed gasliquid partition chromatography. J. Chromatogr. A 11:463-471.

Weel, K. G. C., A. E. M. Boelrijk, J. J. Burger, N. E. Claassen, H Gruppen, A. G. J. Voragen, and G. Smit. 2003. Effect of whey protein on the in vivo release of aldehydes. J. Agric. Food Chem. 51:4746-4752.

Whitson, M., R. E. Miracle, E. Bastian, and M. A. Drake. 2011. Effect of liquid retentate storage on flavor of spray-dried whey protein concentrate and isolate. J. Dairy Sci. 94:3747-3760.

Whitson, M. E., R. E. Miracle, and M. A. Drake. 2010. Sensory characterization of chemical components responsible for cardboard flavor in whey protein. J. Sens. Stud. 25:616-636.
Wright, B. J., S. E. Zevchak, J. M. Wright, and M. A. Drake. 2009. The impact of agglomeration and storage on flavor and flavor stability of whey protein concentrate $80 \%$ and whey protein isolate. J. Food Sci. 74:S17-S29.

Wright, J. M., M. E. Carunchia Whetstine, R. E. Miracle, and M. A. Drake. 2006. Characterization of a cabbage off-flavor in whey protein isolate. J. Food Sci. 71:C86-C90.

Yasosky, J. J., E. D. Aberle, I. C. Peng, E. W. Mills, and M. D. Judge. 1984. Effects of $\mathrm{pH}$ and time of grinding on lipid oxidation of fresh ground pork. J. Food Sci. 49:1510-1512.

Yvon, M., and L. Rijnen. 2001. Cheese flavour formation by amino acid catabolism. Int. Dairy J. 11:185-201. 